\title{
PENGENDALIAN AFLATOKSIN PADA PASCAPANEN JAGUNG MELALUI PENERAPAN HACCP
}

\author{
Miskiyah dan Widaningrum
}

\begin{abstract}
In order to support the self-sufficiency of corn, aflatoxin control system in the supply chains have to be very important attention. Good handling and drying will make longer storage life of corn. Also scheduling in cultivation system, handling, storage and distribution are very important in order to fulfill the need of corn along the year either for food or feed. Due to its problems, the research is conducted on Creating HACCP guidance on handling and storage with follow the Guidance of Compilation Plan HACCP (BSN-Pedoman 1004-1999). Identification of critical point dealing with contamination on corn from harvesting until storage has been conducted. The processing step which is critical on post harvest of corn such as harvesting moment (CCP1), grading (CCP 2), drying moment (CCP3), grading of quality (CCP 4) and storage moment (CCP 5). On the steps above, it needed extra control from the farmer and the seller for controlling the quality of corn in order to avoid the physical contaminant, chemist and microbiology such as fungi and insect which can produce aflatoxins, so it can reduce the weight of corn that is very harming.
\end{abstract}

Keywords:handling, aflatoksin, corn, HACCP

\section{PENDAHULUAN}

Jagung merupakan jenis tanaman serealia yang mempunyai peranan strategis dalam pembangunan pertanian dan perekonomian masyarakat. Salah satu upaya yang dapat dilakukan untuk meningkatkan ketersediaan jagung dan mengurangi ketergantungan terhadap jagung impor adalah dengan penanganan pascapanen yang baik sehingga kehilangan hasil selama kegiatan pascapanen dapat ditekan. Menurut Purwadaria (1987), kegiatan pascapanen jagung meliputi pemanenan, pengangkutan, pengeringan, perontokan dan penyimpanan. Besarnya susut pada kegiatan pascapanen jagung (tidak termasuk pada kegiatan penyimpanan) bervariasi dari 1,2 - 5,2\% susut tercecer dan 5 $10 \%$ susut mutu.

Menurut Syarief dan Halid (1993), penyusutan jagung dapat terjadi akibat penanganan pascapanen yang tidak memadai, adanya gangguan biologis seperti proses respirasi yang tinggi, serangan serangga dan mikroorganisme, serta perubahan fisik seperti tekanan getaran, temperatur, dan kelembaban relatif. Dengan demikian, pencegahan kontaminasi oleh mikroorganisme selama penyimpanan bahan pangan merupakan salah satu upaya yang dapat dilakukan dalam rangka menekan tingkat penyusutan.

Aspergillus flavus adalah cendawan yang sering menyerang jagung, baik selama di lapangan maupun di tempat penyimpanan (Pitt dan Hocking, 1996). Disamping dapat menyebabkan kerusakan bahan pangan serta susut berat, pada kondisi yang sesuai A. flavus dapat memproduksi aflatoksin. Aflatoksin merupakan senyawa karsinogen yang dapat menyebabkan kanker hati pada manusia dan hewan ternak yang mengkonsumsinya secara berlebihan. Oleh karena itu WHO, FAO, dan UNICEF telah menetapkan batas kandungan aflatoksin dalam makanan sumber karbohidrat yang dikonsumsi, tidak lebih dari 30 ppb (Bainton et al., 1980). Bahkan European Commission menetapkan batas maksimal total aflatoksin lebih rendah yaitu $4 \mathrm{ppb}$ untuk produk serealia (Visconti, 1998).

Jagung adalah salah satu komoditas yang mempunyai masalah pada saat penanganan pascapanen, yang ditandai dengan tingginya kontaminasi aflatoksin. Untuk itu diperlukan pendekatan HACCP untuk mengendalikan kontaminasi aflatoksin yang ada pada jagung. Dimana menurut Anonim (2001) pendekatan HACCP merupakan salah satu cara untuk mengendalikan kontaminansi jamur khususnya jamur yang menghasilkan aflatoksin.

HACCP merupakan suatu pendekatan untuk mencegah dan mengontrol penyakit karena keracunan makanan. Sistem ini dirancang untuk mengidentifikasi bahaya yang berhubungan dengan beberapa tahapan produksi, prosesing atau penyiapan makanan, serta memperkirakan resiko yang akan terjadi dan menentukan prosedur operasi untuk prosedur kontrol yang efektif (Bryan, 1992). Sistem HACCP merupakan alat yang tepat untuk menetapkan sistem pengendalian karena berfokus pada pencegahan dari pada pengujian produk akhir. HACCP dapat diterapkan pada seluruh rantai pangan dari 
produk primer sampai pada konsumsi akhir dan penerapannya harus dipandu oleh bukti secara ilmiah terhadap resiko kesehatan manusia.

\section{BAHAN DAN METODE}

Penelitian dilakukan pada bulan April - Oktober tahun 2007. Penelitian dilakukan dengan melakukan survei di tingkat petani yang ada di kabupaten Sukabumi (Jawa Barat), Majalengka (Jawa Barat), dan Sragen (Jawa Tengah) untuk mengetahui proses penanganan pascapanen jagung dari sejak pemanenan sampai dengan penyimpanan yang dilakukan oleh petani. Sedangkan perbaikan proses dilakukan di Laboratorium Pascapanen Bogor.

Dalam penelitian ini dilakukan identifikasi titik-titik kritis terjadinya kontaminasi jagung sejak pemanenan jagung sampai penyimpanan. Studi HACCP dilakukan dengan menggunakan Panduan Penyusunan Rencana HACCP (BSNPedoman 1004-1999). Alat bantu yang digunakan adalah bagan alir proses penanganan pascapanen jagung, tabel penentuan tingkat bahaya/resiko dan CCP decision tree (pohon keputusan $C C P$ ). Sedangkan proses penyusunannya mengikuti tujuh prinsip sistem HACCP yang direkomendasikan oleh Standar Nasional Indonesia (1998) yang dikeluarkan oleh BSN (1999), meliputi: 1) analisis bahaya dan pencegahannya; 2) identifikasi Critical Control Points (CCPs) dalam proses; 3) penetapan batas kritis untuk setiap CCP; 4) penetapan cara pemantauan CCP; 5) penetapan tindakan koreksi; 6) penyusunan prosedur verifikasi, dan 7) penetapan prosedur pencatatan (dokumentasi). Setiap bahan baku dan tahap proses ditentukan termasuk CCP atau tidak, atau hanya $\mathrm{CP}$ melalui pertimbangan tingkat resiko dan berdasarkan jawaban atas pertanyaan dari CCP decision tree (Gambar 1).

Prosesnya berdasarkan 7 prinsip sistem HACCP yang direkomendasikan oleh Standar Nasional Indonesia dari BSN (1999), yang meliputi:

1. Prinsip 1: Analisis bahaya dan pencegahannya

2. Prinsip 2: Identifikasi Critical Control Points (CCP) di dalam proses

3. Prinsip 3: Menetapkan Batas Kritis untuk setiap CCP

4. Prinsip 4: Menetapkan cara pemantauan CCP

5. Prinsip 5: Menetapkan tindakan koreksi

6. Prinsip 6: Menyusun Prosedur Verifikasi
7. Prinsip 7: Menetapkan prosedur pencatatan (dokumentasi)

Analisa bahaya dilakukan dengan mengidentifikasi semua bahaya yang terdapat pada jagung sejak dipanen sampai dengan penyimpanan. Bahaya yang teridentifikasi kemudian disusun dalam sebuah tabel disertai sumber bahaya, tingkat resiko, dan tindakan pencegahannya. Tingkat resiko ditentukan berdasarkan seberapa besar akibat yang ditimbulkan oleh suatu bahaya dan seberapa sering bahaya tersebut mungkin terjadi. Penentuan CCP didasarkan pada pertimbangan tingkat resiko; dan memerlukan pengendalian supaya tidak berbahaya bagi kesehatan manusia. Tahapan proses yang tidak termasuk $C C P$, dapat termasuk Control Point $(C P)$ yang berarti tahapan tersebut apabila tidak dikendalikan dengan baik dapat menyebabkan kecacatan dari segi kualitas.

\section{HASIL DAN PEMBAHASAN}

\subsection{Analisa Bahaya}

Hasil pengamatan terhadap proses penanganan jagung di tingkat petani menunjukkan bahwa penanganan pascapanen jagung masih dilakukan secara manual dengan bantuan peralatan yang sederhana. Dimana pengeringannya dilakukan dengan cara penjemuran dengan sinar matahari dan perontokan atau pemipilannya dilakukan dengan menggunakan tangan. Kondisi penanganan seperti ini sangat rentan terkena infeksi jamur yang berpotensi dalam menghasilkan aflatoksin. Keadaan ini didukung oleh iklim negara kita yang memiliki kelembaban relatif rata-rata cukup tinggi (sekitar 70-80\%), sehingga sangat menguntungkan bagi tumbuhnya jamur, terutama dari jenis Aspergillus. Untuk itu perlu dilakukan perbaikan melalui penerapan HACCP untuk mengendalikan aflatoksin pada jagung.

Langkah penyusunan HACCP diawali dengan pembuatan diagram alir dan konfirmasi diagram alir di tempat (Gambar 2). Gambar 2 menunjukkan tahapan proses kegiatan pascapanen jagung yang dilakukan oleh petani jagung, dan telah disesuaikan dengan perbaikan berdasarkan acuan yang dikemukakan oleh Anonim (1998). Kemudian dilakukan penetapan dan evaluasi potensi-potensi bahaya yang mungkin timbul (Tabel 1). Hasil evaluasi terhadap potensi bahaya menunjukkan bahwa sumber bahaya mikrobiologi (investasi serangga dan infeksi jamur) serta bahaya fisik (kotoran, debu, rambut jagung, ranting, kerusakan mekanis) lebih dominan dibandingkan dengan sumber bahaya yang lain. Adanya investasi 
serangga mengakibatkan biji menjadi rusak sehingga spora jamur penghasil mikotoksin menginfeksi ke dalam jagung. Sedangkan cemaran fisik biasanya berupa kotoran lain yang terikut ketika pengupasan, penjemuran dan pemipilan jagung, kaki pekerja ketika mengupas dan menjemur tongkol jagung. Kerusakan fisik lain yang tidak kalah penting diakibatkan oleh mesin pemipil, dimana biji yang rusak rentan terhadap infestasi jamur yang mencemari jagung.

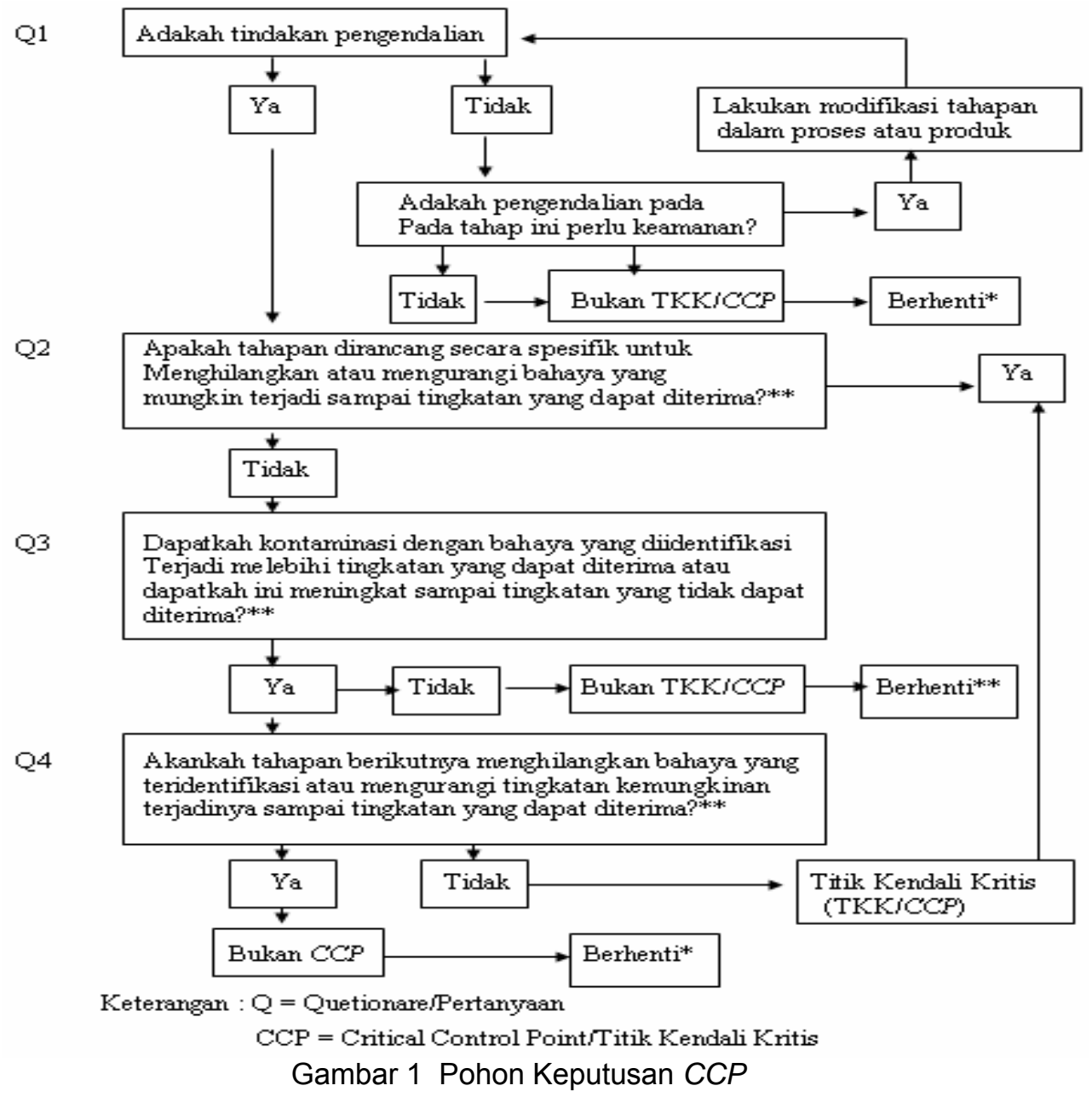

\subsection{Penentuan Titik Kritis (CP) dan Titik Kendali Kritis (CCP)}

Penetapan titik kritis dilakukan berdasarkan pohon keputusan seperti yang terdapat pada Gambar 1, yang kemudian dituangkan pada Tabel 1 dan Tabel 2. Hal tersebut dilakukan setelah potensi bahaya teridentifikasi. Pada Tabel 1 menunjukkan bahwa tahapan pengupasan, pemipilan, pembersihan, dan pengemasan termasuk dalam CP (Control Points) atau titik-titik yang perlu dikontrol secara rutin. Sehingga cukup dengan mengontrol setiap tahapan tersebut secara rutin, bahaya yang mungkin timbul dapat diminimalkan.

Adapun titik-titik kritis pada tahapan penanganan pascapanen yang sangat perlu diperhatikan dan evaluasi batas-batas kritisnya yang harus dipenuhi (Critical Control Points/CCP) seperti terlihat pada Tabel 2. Dimana titik tersebut merupakan tahapan proses penanganan pascapanen jagung yang sangat perlu dikontrol pada setiap kali penanganan, yang apabila tidak dilakukan pengontrolan dapat menimbulkan bahaya, baik pada produknya maupun pengguna yang mengkonsumsinya. Bahaya tersebut dapat berupa bahaya fisik, kimia, dan mikrobiologi.

Identifikasi titik-titik kritis terjadinya kontaminasi pada jagung sejak jagung dipanen sampai pada saat penyimpanan telah dilakukan. Tahapan proses yang menjadi titik kritis pada proses pascapanen jagung adalah pada saat pemanenan (CCP 1), sortasi (CCP 2), pengeringan (CCP 3), sortasi mutu (CCP 4) serta penyimpanan (CCP 5). Pada tahapan 
tersebut, diperlukan perhatian lebih dari petani dan pengumpul untuk menjaga mutu biji jagung agar terhindar dari kontaminasi fisik, kimia dan mikrobiologi seperti jamur serta serangga yang dapat menghasilkan aflatoksin dan merugikan nilai mutu daripada jagung yang diproduksi, sehingga pada akhirnya susut mutu dapat merugikan petani dan pedagang sendiri akibat ditolaknya produk mereka oleh konsumen secara umum, atau diterima namun dengan harga yang lebih rendah.

\subsection{Penyusunan Lembar HACCP}

Berdasarkan hasil pengamatan terhadap titik kritis (CP) dan titik kendali kritis (CCP), kemudian disusun lembaran HACCP dengan mengacu pada Anonim (1998) seperti terlihat pada Tabel 4 dan 5 . Tabel 4 menunjukkan diskripsi produk jagung berdasarkan persyaratan kualitatif dan kuantitatif seperti yang direkomendasikan oleh Anonim (1998).

Langkah selanjutnya adalah proses dokumentasi dan verifikasi rencana HACCP. Proses dokumentasi hendaknya dilakukan oleh dinas pertanian dengan dinas terkait di daerah setempat, sedang proses verifikasi dapat dilakukan oleh penyuluh atau GAPOKTAN (Gabungan Kelompok Tani) sekaligus menjadi proses audit untuk meyakinkan bermanfaatnya penerapan sistem HACCP yang telah disusun, sehingga cukup dengan mengendalikan prosesproses yang ditetapkan sebagai CCP.

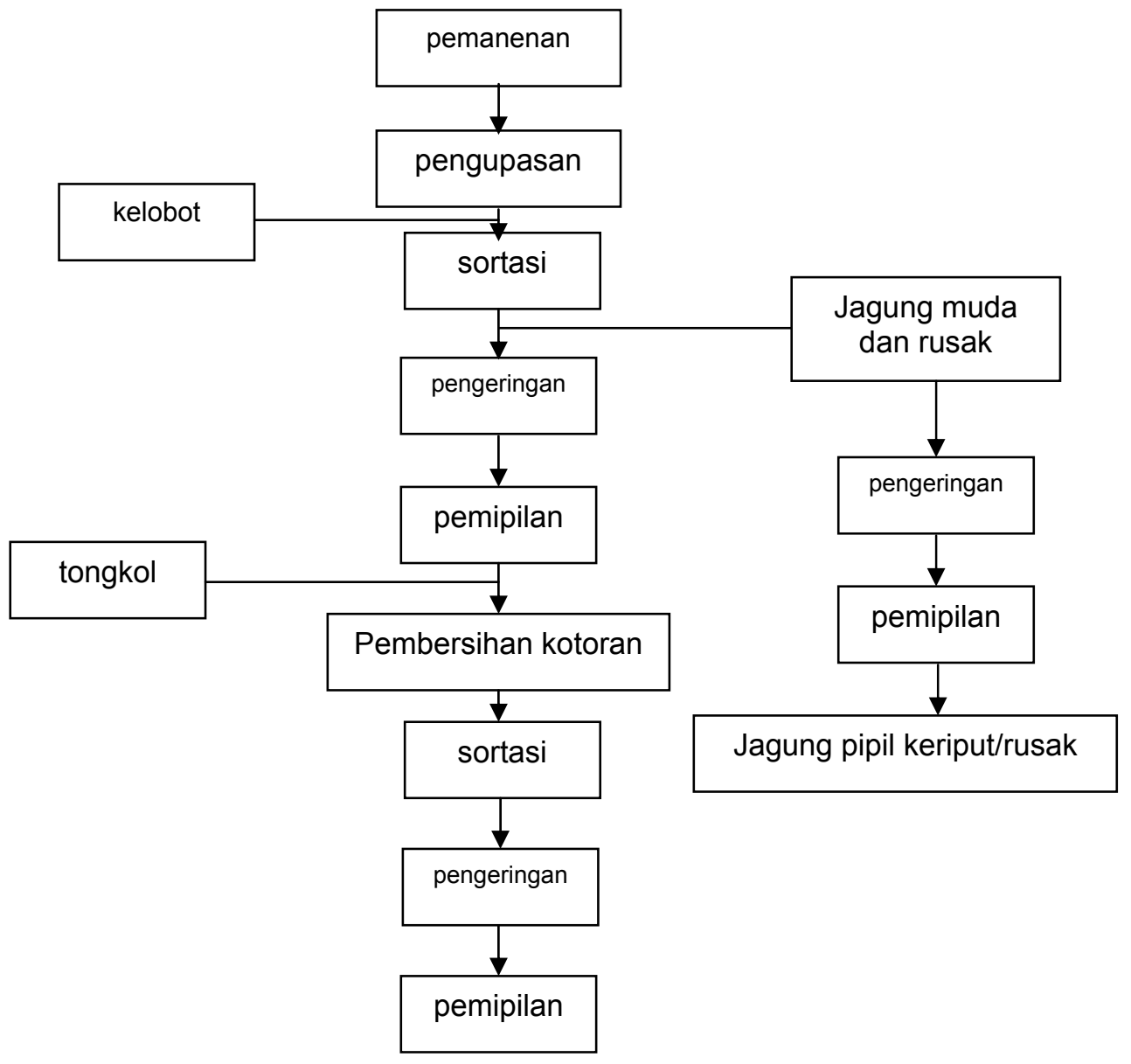

Gambar 2 Diagram Alir Pascapanen Jagung ditingkat Petani 
Tabel 1 Analisa Bahaya Penanganan Pascapanen Jagung

\begin{tabular}{|c|c|c|c|c|c|c|c|c|c|}
\hline \multirow[b]{2}{*}{ No } & \multirow[b]{2}{*}{ Bahan } & \multirow[b]{2}{*}{ Bahaya } & \multicolumn{2}{|c|}{$\begin{array}{l}\text { Bahaya } \\
\text { terhadap }\end{array}$} & \multirow[b]{2}{*}{$\begin{array}{l}\text { Penyebab } \\
\text { bahaya }\end{array}$} & \multicolumn{3}{|c|}{ Penting tidaknya (T/S/R) } & \multirow[b]{2}{*}{ Tindakan pengendalian } \\
\hline & & & $\begin{array}{l}\text { Kesela } \\
\text {-matan }\end{array}$ & Mutu & & Peluang & $\begin{array}{c}\text { Kepara } \\
\text { han }\end{array}$ & $\begin{array}{l}\text { Penting } \\
\text { /tdk }\end{array}$ & \\
\hline 1 & $\begin{array}{l}\text { Pemane- } \\
\text { nan }\end{array}$ & $\begin{array}{l}\text { M: jamur, } \\
\text { serangga }\end{array}$ & $\sqrt{ }$ & $\sqrt{ }$ & $\begin{array}{l}\text { M: kontaminasi } \\
\text { dengan jamur } \\
\text { pada saat } \\
\text { panen, infestasi } \\
\text { serangga }\end{array}$ & $T$ & $T$ & $\mathrm{~T}$ & $\begin{array}{l}\text { - panen tepat waktu } \\
\text { (umur } 75-80 \text { hari) } \\
\text { - Pemanenan secepat } \\
\text { mungkin dan langsung } \\
\text { dikeringkan sd KA yang } \\
\text { dipersyaratkan, hindari } \\
\text { infestasi serangga yang } \\
\text { memicu tumbuhnya jamur }\end{array}$ \\
\hline 2 & \begin{tabular}{|l|} 
Pengupasan \\
kulit/kelobot
\end{tabular} & $\begin{array}{l}\text { M: jamur, } \\
\text { serangga } \\
\text { F: kotoran, } \\
\text { rambut } \\
\text { jagung, } \\
\text { ranting, } \\
\text { debu }\end{array}$ & $\sqrt{ }$ & $\sqrt{ }$ & $\begin{array}{l}\text { M: kontaminasi } \\
\text { dengan jamur } \\
\text { penghasil } \\
\text { mikotoksin, } \\
\text { adanya } \\
\text { infestasi } \\
\text { serangga } \\
\text { sehingga biji } \\
\text { rusak dan } \\
\text { terjadi infeksi } \\
\text { mikotoksin } \\
\mathrm{F} \text { adanya } \\
\text { rambut jagung } \\
\text { atau ranting/kotoran } \\
\text { lain yang terikut } \\
\text { ketika } \\
\text { pengupasan } \\
\text { jagung, kaki } \\
\text { pekerja ketika } \\
\text { mengupas } \\
\text { jagung }\end{array}$ & $\mathrm{T}$ & $\mathrm{T}$ & $\mathrm{T}$ & $\begin{array}{l}\text { - Pengupasan secepat } \\
\text { mungkin, hindari } \\
\text { serangga yang dapat } \\
\text { mengakibatkan biji rentan } \\
\text { terhadap serangan jamur } \\
\text { - bersihkan kotoran } \\
\text { yang terikut ketika } \\
\text { pengupasan jagung, } \\
\text { pekerja menggunakan } \\
\text { sandal/alas kaki }\end{array}$ \\
\hline 3 & sortasi & $\begin{array}{l}\text { M: jamur, } \\
\text { serangga } \\
\text { F: batu, } \\
\text { ranting, } \\
\text { rambut } \\
\text { jagung, dll }\end{array}$ & $\sqrt{ }$ & $\sqrt{ }$ & $\begin{array}{l}\text { M: bebas dari } \\
\text { jagung yang } \\
\text { terserang hama } \\
\text { dan penyakit } \\
\text { F: adanya } \\
\text { rambut jagung, } \\
\text { ranting /kotoran } \\
\text { lain yang terikut } \\
\text { ketika sortasi } \\
\text { jagung }\end{array}$ & $T$ & $T$ & $\mathrm{~T}$ & $\begin{array}{l}\text { - sortasi dilakukan } \\
\text { dengan melakukan } \\
\text { pemisahan antara jagung } \\
\text { muda dengan jagung tua } \\
\text { - sortasi jagung yang } \\
\text { berjamur } \\
\text { - pisahkan rambut } \\
\text { jagung, ranting atau } \\
\text { kotoran lainnya } \\
\text { - higiene pekerja ketika } \\
\text { sortasi } \\
\text { - sanitasi lingkungan }\end{array}$ \\
\hline 4 & Pengeringan & $\begin{array}{l}\text { M: jamur, } \\
\text { serangga } \\
\text { F : } \\
\text { kotoran, } \\
\text { rambut } \\
\text { jagung, } \\
\text { ranting, dll }\end{array}$ & $\sqrt{ }$ & $\sqrt{ }$ & $\begin{array}{l}\text { M: kontaminasi } \\
\text { silang dengan } \\
\text { jamur pada } \\
\text { saat } \\
\text { pengeringan, } \\
\text { dan infestasi } \\
\text { serangga } \\
\text { F: adanya } \\
\text { kotoran yang } \\
\text { terikut ketika } \\
\text { pengeringan } \\
\text { jagung }\end{array}$ & $\mathrm{R}$ & $\mathrm{R}$ & $\mathrm{R}$ & $\begin{array}{l}\text { - pengeringan secepat } \\
\text { mungkin sampai kadar air } \\
15 \% \\
\text { - bersihkan kotoran } \\
\text { yang terikut ketika proses } \\
\text { pengeringan } \\
\text { - higiene pekerja } \\
\text { menggunakan alas kaki \& } \\
\text { sanitasi lingkungan } \\
\text { - pengeringan dengan } \\
\text { alas/terpal dan proses } \\
\text { pembalikan } \\
\text { menggunakan alat }\end{array}$ \\
\hline
\end{tabular}




\begin{tabular}{|c|c|c|c|c|c|c|c|c|c|}
\hline 5 & Pemipilan & $\begin{array}{l}\text { M : jamur, } \\
\text { serangga } \\
\text { F: } \\
\text { kerusakan } \\
\text { karena } \\
\text { pemipilan } \\
\text { dengan } \\
\text { mesin, } \\
\text { adanya } \\
\text { kotoran, } \\
\text { rambut } \\
\text { jagung, } \\
\text { ranting, dll }\end{array}$ & $\sqrt{ }$ & $\sqrt{ }$ & $\begin{array}{l}\text { M : kontaminasi } \\
\text { silang dengan } \\
\text { jamur pada } \\
\text { saat pemipilan } \\
\text { F : adanya } \\
\text { kerusakan fisik } \\
\text { dan kotoran } \\
\text { yang terikut } \\
\text { ketika proses } \\
\text { pemipilan } \\
\text { jagung }\end{array}$ & $T$ & $\mathrm{~T}$ & $\mathrm{~T}$ & $\begin{array}{l}\text { - pemipilan dilakukan } \\
\text { mesin/manual dengan KA } \\
\text { yang tepat sehingga tidak } \\
\text { mudah terinfeksi jamur } \\
\text { pada bijian yang rusak } \\
\text { - bersihkan kotoran } \\
\text { yang terikut ketika proses } \\
\text { pemipilan }\end{array}$ \\
\hline 6 & $\begin{array}{l}\text { Pembersih } \\
\text { an }\end{array}$ & $\begin{array}{l}\text { M: jamur, } \\
\text { serangga, } \\
\text { bakteri }\end{array}$ & $\sqrt{ }$ & $\sqrt{ }$ & $\begin{array}{l}\text { M : adanya biji } \\
\text { yang terinfeksi } \\
\text { jamur dan } \\
\text { adanya } \\
\text { infestasi } \\
\text { serangga, } \\
\text { tangan dan } \\
\text { kaki pekerja } \\
\text { F : adanya } \\
\text { kotoran yang } \\
\text { terikut ketika } \\
\text { proses } \\
\text { pembersihan } \\
\text { jagung }\end{array}$ & $S$ & $\mathrm{~S}$ & $\mathrm{~S}$ & $\begin{array}{l}\text { - bersihkan kotoran } \\
\text { yang terikut ketika proses } \\
\text { pembersihan dengan } \\
\text { kotoran maksimal } 5 \% \\
\text { - higiene pekerja dan } \\
\text { sanitasi lingkungan }\end{array}$ \\
\hline 7 & $\begin{array}{l}\text { Sortasi } \\
\text { mutu }\end{array}$ & $\begin{array}{l}\text { M: jamur, } \\
\text { serangga, } \\
\text { bakteri } \\
\text { F: } \\
\text { kotoran,ra } \\
\text { nting, dll }\end{array}$ & $\sqrt{ }$ & $\sqrt{ }$ & $\begin{array}{l}\mathrm{M} \text { : adanya biji } \\
\text { yang berjamur, } \\
\text { kaki dan } \\
\text { tangan pekerja } \\
\mathrm{F} \text { : adanya } \\
\text { ranting /kotoran } \\
\text { lain yang terikut } \\
\text { ketika sortasi }\end{array}$ & $\mathrm{T}$ & $\mathrm{T}$ & $\mathrm{T}$ & 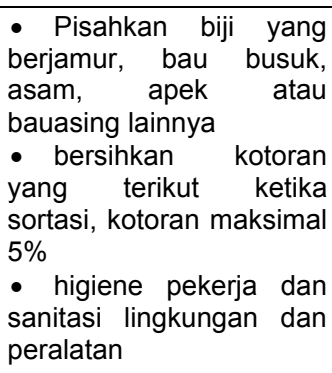 \\
\hline 8 & $\begin{array}{l}\text { Pengema- } \\
\text { san }\end{array}$ & $\begin{array}{l}\text { M: jamur, } \\
\text { serangga, } \\
\text { bakteri }\end{array}$ & & $\sqrt{ }$ & $\begin{array}{l}\text { M: adanya biji } \\
\text { yang berjamur, } \\
\text { kaki dan } \\
\text { tangan pekerja } \\
\text { F: adanya } \\
\text { kotoran pada } \\
\text { pengemas dan } \\
\text { alat pengemas } \\
\text { lainnya }\end{array}$ & $\mathrm{R}$ & $\mathrm{R}$ & $\mathrm{R}$ & $\begin{array}{l}\text { - Operator memakai } \\
\text { sepatu boot steril (bersih) } \\
\text { dan atau pelindung kaki } \\
\text { pada saat pengemasan } \\
\text { jagung, higiene pekerja } \\
\text { - Sanitasi peralatan } \\
\text { pengemas r dan } \\
\text { ingkungan }\end{array}$ \\
\hline 9 & $\begin{array}{l}\text { Penyimpa- } \\
\text { nan }\end{array}$ & $\begin{array}{l}\text { M: jamur, } \\
\text { serangga } \\
\text { F: debu } \\
\text { dan } \\
\text { kotoran } \\
\text { lainnya }\end{array}$ & $\sqrt{ }$ & $\sqrt{ }$ & $\begin{array}{l}\text { M: kontaminasi } \\
\text { dengan jamur } \\
\text { pada tempat } \\
\text { penyimpan, } \\
\text { terjadi } \\
\text { kontaminasi } \\
\text { silang dan } \\
\text { infestasi } \\
\text { serangga } \\
\mathrm{F} \text { : adanya } \\
\text { ranting /kotoran } \\
\text { lain yang terikut } \\
\text { ketika berada } \\
\text { di tempat } \\
\text { penyimpanan }\end{array}$ & $\mathrm{T}$ & $\mathrm{T}$ & $\mathrm{T}$ & 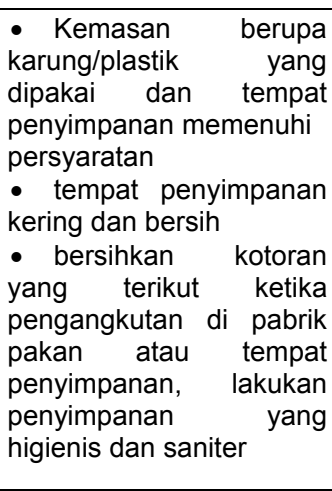 \\
\hline
\end{tabular}


Tabel 2 Matriks CP pada Pengelolaan Pascapanen Jagung

\begin{tabular}{|c|c|c|c|c|c|c|}
\hline \multirow[t]{2}{*}{ Tahap } & \multirow{2}{*}{$\begin{array}{l}\text { CP } \\
\text { No. }\end{array}$} & \multirow{2}{*}{$\begin{array}{c}\text { Jenis } \\
\text { Bahaya }\end{array}$} & \multirow[t]{2}{*}{ Batas Kritis } & \multicolumn{2}{|c|}{ Monitoring } & \multirow{2}{*}{$\begin{array}{c}\text { Tindakan } \\
\text { Koreksi }\end{array}$} \\
\hline & & & & Metode & Frekuensi & \\
\hline Pengupasan & 1 & $\begin{array}{l}\text { Biologi } \\
\text { Fisik }\end{array}$ & $\begin{array}{l}\text { Kontaminasi } \\
\text { silang } \\
\text { Bebas dari } \\
\text { kelobot dan } \\
\text { rambut jagung }\end{array}$ & $\begin{array}{l}\text { Cek secara } \\
\text { visual }\end{array}$ & $\begin{array}{l}\text { Setiap tahap } \\
\text { pengupasan }\end{array}$ & $\begin{array}{l}\text { Dibersihkan } \\
\text { kembali }\end{array}$ \\
\hline Pemipilan & 2 & $\begin{array}{l}\text { Biologi } \\
\text { Fisik }\end{array}$ & $\begin{array}{l}\text { Ukuran tongkol } \\
\text { seragam }\end{array}$ & $\begin{array}{l}\text { Cek secara } \\
\text { visual }\end{array}$ & $\begin{array}{l}\text { Setiap proses } \\
\text { pemipilan }\end{array}$ & sortasi \\
\hline Pembersihan & 3 & $\begin{array}{l}\text { Biologi } \\
\text { Fisik }\end{array}$ & $\begin{array}{l}\text { Kotoran } \\
\text { maksimal 5\% }\end{array}$ & $\begin{array}{l}\text { Cek secara } \\
\text { visual }\end{array}$ & $\begin{array}{l}\text { Setiap tahap } \\
\text { pembersihan }\end{array}$ & $\begin{array}{l}\text { Pembersihan } \\
\text { ulang } \\
\text { Buang jagung } \\
\text { berjamur }\end{array}$ \\
\hline Pengemasan & 4 & $\begin{array}{l}\text { Biologi } \\
\text { Fisik }\end{array}$ & $\begin{array}{l}\text { Bahan } \\
\text { pengemas } \\
\text { bebas dari } \\
\text { kotoran } \\
\text { Ukuran } \\
\text { seragam }\end{array}$ & $\begin{array}{l}\text { Cek secara } \\
\text { visual } \\
\text { penimbangan }\end{array}$ & $\begin{array}{l}\text { Setiap proses } \\
\text { pengemasan }\end{array}$ & $\begin{array}{l}\text { Gunakan } \\
\text { pengemas yang } \\
\text { bersih } \\
\text { Timbang ulang }\end{array}$ \\
\hline
\end{tabular}

Tabel 3 Matriks CCP pada Pengelolaan Pascapanen Jagung

\begin{tabular}{|c|c|c|c|c|c|c|}
\hline \multirow[t]{2}{*}{ Tahap } & \multirow{2}{*}{$\begin{array}{l}\text { CCP } \\
\text { No. }\end{array}$} & \multirow{2}{*}{$\begin{array}{c}\text { Jenis } \\
\text { Bahaya }\end{array}$} & \multirow[t]{2}{*}{ Batas Kritis } & \multicolumn{2}{|l|}{ Monitoring } & \multirow{2}{*}{$\begin{array}{c}\text { Tindakan } \\
\text { Koreksi }\end{array}$} \\
\hline & & & & Metode & Frekuensi & \\
\hline $\begin{array}{l}\text { Pema- } \\
\text { nenan }\end{array}$ & 1 & $\begin{array}{l}\text { Mikro- } \\
\text { biologi }\end{array}$ & Umur $75-80$ hari & $\begin{array}{l}\text { o Melihat jadwal tanam } \\
\text { o Batang, daun, dan kelobot buah } \\
\text { jagung berubah menjadi kuning } \\
\text { atau mulai mengering } \\
\text { o bila jagung dikupas biji jagung } \\
\text { nampak keras, bernas dan } \\
\text { mengkilap } \\
\text { o bila ditekan dengan kuku tangan } \\
\text { pada biji jagung tidak nampak } \\
\text { bekas tekanan }\end{array}$ & Setiap panen & $\begin{array}{l}\text { Pisahkan } \\
\text { tongkol } \\
\text { jagung yang } \\
\text { terinfeksi } \\
\text { serangga/ } \\
\text { jamur }\end{array}$ \\
\hline Sortasi & 2 & $\begin{array}{l}\text { Mikro- } \\
\text { biologi }\end{array}$ & $\begin{array}{l}\text { o Bebas dari jagung } \\
\text { tongkol muda } \\
\text { o Bebas dari jagung } \\
\text { yang terserang } \\
\text { hama dan penyakit }\end{array}$ & Cek secara visual & $\begin{array}{l}\text { setiap tahap } \\
\text { sortasi }\end{array}$ & Sortasi ulang \\
\hline $\begin{array}{l}\text { Pengeri } \\
\text { ngan }\end{array}$ & 3 & $\begin{array}{l}\text { Mikro- } \\
\text { biologi }\end{array}$ & Kadar air 15\% & $\begin{array}{l}\text { o Bila antar biji jagung digesek- } \\
\text { gesek akan terdengar bunyi } \\
\text { kresek yang nyaring dan atau } \\
\text { o Uji kadar air }\end{array}$ & $\begin{array}{l}\text { Setiap tahap } \\
\text { pengeringan }\end{array}$ & $\begin{array}{l}\text { Dilanjutkan } \\
\text { pengeringan }\end{array}$ \\
\hline $\begin{array}{l}\text { Sortasi } \\
\text { Mutu }\end{array}$ & 4 & $\begin{array}{l}\text { Mikro- } \\
\text { biologi }\end{array}$ & $\begin{array}{l}\text { o Biji jagung bebas } \\
\text { dari bau busuk, } \\
\text { masam, apek, atau } \\
\text { bau asing lainnya } \\
\text { o Kadar kotoran } \\
\text { maksimal } 5 \%\end{array}$ & $\begin{array}{l}\text { o Cek dengan indera } \\
\text { o Cek secara visual }\end{array}$ & $\begin{array}{l}\text { Setiap tahap } \\
\text { sortasi }\end{array}$ & Sortasi ulang \\
\hline $\begin{array}{l}\text { Penyim } \\
\text { panan }\end{array}$ & 5 & $\begin{array}{l}\text { Mikro- } \\
\text { biologi }\end{array}$ & $\begin{array}{l}\text { Tempat penyimpanan } \\
\text { kering dan bersih }\end{array}$ & Cek sanitasi & $\begin{array}{l}\text { Setiap tahap } \\
\text { penyimpanan }\end{array}$ & Pembersihan \\
\hline
\end{tabular}


Tabel 4 Diskripsi Produk

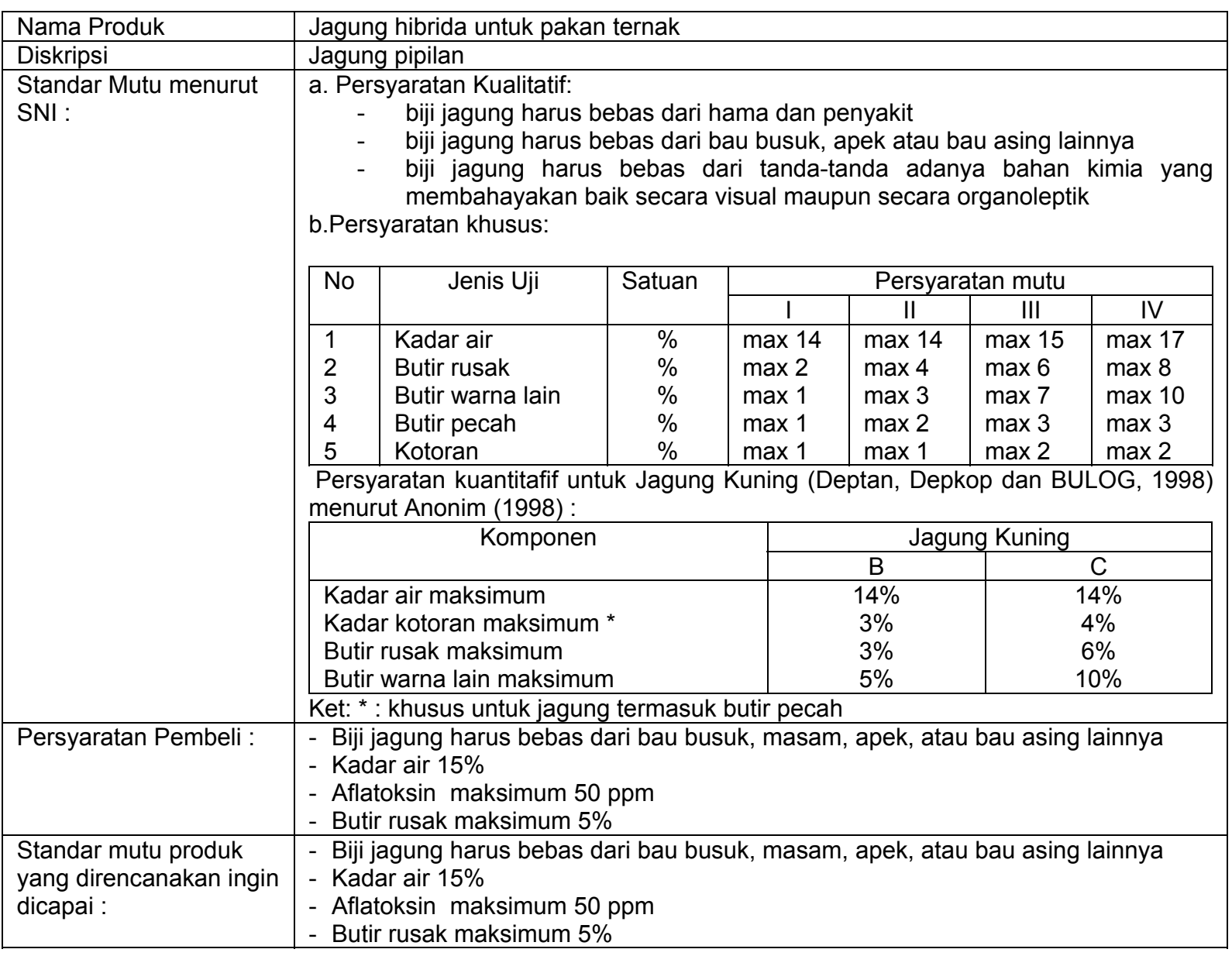

Tabel 5 Lembaran Rencana HACCP Penanganan Pascapanen Jagung untuk Mengendalikan Aflatoksin

\begin{tabular}{|c|c|c|c|c|c|c|c|}
\hline $\begin{array}{c}\text { Tahapan } \\
\text { proses }\end{array}$ & $\begin{array}{l}\text { Diskripsi } \\
\text { bahaya }\end{array}$ & $\begin{array}{c}\text { Kemungkinan untuk } \\
\text { mengkontrol }\end{array}$ & $\begin{array}{c}\text { Langkah } \\
\text { Kontrol }\end{array}$ & Batas Kritis & Prosedur monitoring & $\begin{array}{c}\text { Tindakan } \\
\text { koreksi }\end{array}$ & Catatan \\
\hline Pemanenan & $\begin{array}{l}\text { Jamur/ } \\
\text { kontaminasi } \\
\text { aflatoksin }\end{array}$ & Panen tepat waktu & CCP 1 & $\begin{array}{l}\text { Umur } 75-80 \\
\text { hari }\end{array}$ & $\begin{array}{l}\text { - Melihat jadwal tanam } \\
\text { - Batang, daun, dan } \\
\text { kelobot buah jagung } \\
\text { berubah menjadi kuning } \\
\text { atau mulai mengering } \\
\text {-bila jagung dikupas biji } \\
\text { jagung nampak keras, } \\
\text { bernas dan mengkilap } \\
\text {-bila ditekan dengan kuku } \\
\text { tangan pada biji jagung } \\
\text { tidak nampak bekas } \\
\text { tekanan }\end{array}$ & $\begin{array}{l}\text { Pisahkan } \\
\text { tongkol jagung } \\
\text { yang terinfeksi } \\
\text { serangga/jamur }\end{array}$ & $\begin{array}{l}\text { Catatan \%tase } \\
\text { hasil sortasi }\end{array}$ \\
\hline pengupasan & $\begin{array}{l}\text { jamur, } \\
\text { serangga } \\
\text { Kotoran, } \\
\text { rambut } \\
\text { jagung, } \\
\text { ranting, } \\
\text { debu }\end{array}$ & $\begin{array}{l}\text { Minimalkan waktu } \\
\text { pengupasan } \\
\text { Sanitasi lingkungan } \\
\text { Higiene pekerja }\end{array}$ & GAP & $\begin{array}{l}\text { Bebas dari } \\
\text { kelobot dan } \\
\text { rambut jagung }\end{array}$ & $\begin{array}{l}\text {-Pengupasan dilakukan } \\
\text { secepat mungkin, hindari } \\
\text { serangga yang dapat } \\
\text { mengakibatkan biji rentan } \\
\text { terhadap serangan jamur } \\
\text {-bersihkan kotoran yang } \\
\text { terikut ketika } \\
\text { pengupasan jagung, } \\
\text { pekerja menggunakan } \\
\text { sandal/alas }\end{array}$ & $\begin{array}{l}\text { Dibersihkan } \\
\text { kembali }\end{array}$ & \\
\hline Sortasi & $\begin{array}{l}\text { jamur, } \\
\text { serangga } \\
\text { batu, }\end{array}$ & $\begin{array}{l}\text { Sortasi dilakukan } \\
\text { oleh pekerja yang } \\
\text { terlatih dan teliti }\end{array}$ & CCP2 & $\begin{array}{l}\text { Bebas dari } \\
\text { jagung tongkol } \\
\text { muda }\end{array}$ & Cek secara visual & Sortasi ulang & $\begin{array}{l}\text { Jumlah jagung } \\
\text { yang memenuhi } \\
\text { syarat }\end{array}$ \\
\hline
\end{tabular}




\begin{tabular}{|c|c|c|c|c|c|c|c|}
\hline $\begin{array}{l}\text { Tahapan } \\
\text { proses }\end{array}$ & $\begin{array}{l}\text { Diskripsi } \\
\text { bahaya }\end{array}$ & $\begin{array}{c}\text { Kemungkinan untuk } \\
\text { mengkontrol }\end{array}$ & $\begin{array}{c}\text { Langkah } \\
\text { Kontrol }\end{array}$ & Batas Kritis & Prosedur monitoring & $\begin{array}{c}\text { Tindakan } \\
\text { koreksi }\end{array}$ & Catatan \\
\hline & $\begin{array}{l}\text { ranting, } \\
\text { rambut } \\
\text { jagung, dll }\end{array}$ & & & $\begin{array}{l}\text { Bebas dari } \\
\text { jagung yang } \\
\text { terserang hama } \\
\text { dan penyakit }\end{array}$ & & & \\
\hline Pengeringan & $\begin{array}{l}\text { jamur, } \\
\text { serangga } \\
\text { kotoran, } \\
\text { rambut } \\
\text { jagung, } \\
\text { ranting, dll }\end{array}$ & $\begin{array}{l}\text { Keringkan tongkol } \\
\text { jagung sampai Aw } \\
\text { yang aman }(0,82) \\
\text { Hindarkan } \\
\text { rewetting(lembab } \\
\text { kembali) dengan } \\
\text { ventilasi } \\
\text { penyimpanan yang } \\
\text { maksimal } \\
\text { Keringkan bijian pada } \\
\text { KA yang aman }\end{array}$ & CCP3 & Kadar air $15 \%$ & $\begin{array}{l}\text {-Bila antar biji jagung } \\
\text { digesek-gesek akan } \\
\text { terdengar bunyi kresek } \\
\text { yang nyaring dan atau } \\
\text {-Uji kadar air }\end{array}$ & $\begin{array}{l}\text { Dilanjutkan } \\
\text { pengeringan }\end{array}$ & \\
\hline Pemipilan & $\begin{array}{l}\text { jamur, } \\
\text { serangga } \\
\text { kerusakan } \\
\text { karena } \\
\text { pemipilan } \\
\text { dengan } \\
\text { mesin, } \\
\text { adanya } \\
\text { kotoran, } \\
\text { rambut } \\
\text { jagung, } \\
\text { ranting, dll }\end{array}$ & $\begin{array}{l}\text { Minimalkan bijian } \\
\text { yang pecah melalui } \\
\text { pemipilan }\end{array}$ & GAP & $\begin{array}{l}\text { Ukuran tongkol } \\
\text { seragam }\end{array}$ & -Cek secara visual & sortasi & \\
\hline Pembersihan & $\begin{array}{l}\text { jamur, } \\
\text { serangga, } \\
\text { bakteri } \\
\text { adanya } \\
\text { kotoran, } \\
\text { rambut } \\
\text { jagung, } \\
\text { ranting, dll } \\
\end{array}$ & $\begin{array}{l}\text { Higiene pekerja dan } \\
\text { sanitasi lingkungan } \\
\text { dan peralatan } \\
\text { Pekerja yang terampil } \\
\text { Insektisida, hindari } \\
\text { debu atau bahan } \\
\text { organik lain }\end{array}$ & GAP & $\begin{array}{l}\text { Kotoran } \\
\text { maksimal 5\% }\end{array}$ & Cek secara visual & Sortasi ulang & \\
\hline Sortasi mutu & $\begin{array}{l}\text { jamur, } \\
\text { serangga, } \\
\text { bakteri } \\
\text { kotoran,rant } \\
\text { ing, dll }\end{array}$ & $\begin{array}{l}\text { Sortasi dilakukan } \\
\text { oleh pekerja yang } \\
\text { terlatih dan teliti }\end{array}$ & CCP4 & $\begin{array}{l}\text { Biji jagung } \\
\text { bebas dari bau } \\
\text { busuk, masam, } \\
\text { apek, atau bau } \\
\text { asing lainnya } \\
\text { Kadar kotoran } \\
\text { maksimal 5\% }\end{array}$ & $\begin{array}{l}\text { Cek dengan indera } \\
\text { Cek secara visual }\end{array}$ & Sortasi ulang & $\begin{array}{l}\text { Jumlah jagung } \\
\text { yang memenuhi } \\
\text { syarat }\end{array}$ \\
\hline Pengemasan & $\begin{array}{l}\text { jamur, } \\
\text { serangga, } \\
\text { bakteri } \\
\text { debu, } \\
\text { kelobot, } \\
\text { kotoran } \\
\text { lainnya }\end{array}$ & $\begin{array}{l}\text { Pengemasan } \\
\text { dilakukan dengan } \\
\text { teliti dan } \\
\text { menggunakan } \\
\text { pengemas yang } \\
\text { bersih dan kuat }\end{array}$ & GAP & $\begin{array}{l}\text { Bahan } \\
\text { pengemasa } \\
\text { bebas dari } \\
\text { kotoran } \\
\text { Ukuran } \\
\text { seragam }\end{array}$ & $\begin{array}{l}\text { Cek secara visual } \\
\text { Penimbangan }\end{array}$ & $\begin{array}{l}\text { Gunakan } \\
\text { pengemas yang } \\
\text { bersih } \\
\text { Timbang ulang }\end{array}$ & Jumlah produksi \\
\hline Penyimpanan & $\begin{array}{l}\text { jamur, } \\
\text { serangga } \\
\text { debu dan } \\
\text { kotoran } \\
\text { lainnya }\end{array}$ & $\begin{array}{l}\text { Sanitasi lingkungan } \\
\text { dan higienen pekerja } \\
\text { Hindarkan } \\
\text { rewetting(lembab } \\
\text { kembali) dengan } \\
\text { ventilasi } \\
\text { penyimpanan yang } \\
\text { maksimal } \\
\text { Keringkan bijian pada } \\
\text { KA yang aman } \\
\end{array}$ & CСР 5 & $\begin{array}{l}\text { Tempat } \\
\text { penyimpanan } \\
\text { kering dan } \\
\text { bersih }\end{array}$ & Cek sanitasi & pembersihan & \\
\hline
\end{tabular}




\section{KESIMPULAN}

a. Penanganan jagung di tingkat petani sampai saat ini masih dilakukan secara manual dengan bantuan peralatan yang masih sangat sederhana. Pengeringannya dilakukan dengan cara penjemuran dan perontokannya dilakukan dengan menggunakan tangan

b. Identifikasi titik-titik kritis terjadinya kontaminasi pada jagung sejak jagung dipanen sampai pada saat penyimpanan telah dilakukan.Tahapan proses yang menjadi titik kritis pada proses pascapanen jagung adalah pada saat pemanenan (CCP 1), sortasi (CCP 2), pengeringan ( $\mathrm{CCP} 3$ ), sortasi mutu (CCP 4) serta penyimpanan (CCP 5).

c. Diperlukan perhatian lebih dari petani dan pengumpul untuk menjaga mutu biji jagung agar terhindar dari kontaminasi fisik, kimia dan mikrobiologi seperti jamur serta serangga yang dapat menghasilkan aflatoksin dan merugikan nilai mutu jagung yang diproduksi

d. Penanganan dan pengeringan yang baik akan memberikan daya simpan yang baik pula bagi jagung tersebut. Disamping itu sistem penjadwalan dalam sistem penanaman, penanganan, penyimpanan dan distribusi menjadi penting artinya dalam rangka pemenuhan kebutuhan jagung sepanjang tahun baik untuk pangan maupun pakan.

\section{DAFTAR PUSTAKA}

1. Anonim. 1998. Pedoman Penyusunan Rencana Kerja Jaminan Mutu Penanganan Pascapanen Jagung, Pusat Standardisasi dan Akreditasi Sekretariat Jendral Deptan. Jakarta.
2. Anonim, 2001. Manual on the Applicatin HACCP to Mycotoxin Prevention and Control. FAO. Rome. Italy.

3. BSN, 1999. Pedoman Penyusunan Rencana Sistem Analisa Bahaya dan Pengendalian Titik Kritis (HACCP). Badan Standardisasi Nasional. Pedoman 1004-1999.

4. Bryan, 1992. Hazard Analysis Critical Control Point Evaluations. World Health Organization. Geneva.

5. Pitt, J.I. and A.D. Hocking, 1996. Fungi and Food Spoilage. Blackie Academic and Professional, London.

6. Purwadaria, H.K. 1987. Teknologi Penanganan Pascapanen Jagung. Deptan FAO. UNDP. Development and Utilization of Postharvest Tools and Equipment.

7. Syarief, R. dan H. Halid, 1993. Teknologi Penyimpanan Pangan. ARCAN, Jakarta.

8. Visconti, A. 1998. New European Union Regulation for Aflatoxin in Foodstuffs. Mycotoxicology Nedwsletter 4(2): 1.

\section{BIODATA}

Miskiyah, S.Pt.M.P., dilahirkan di Blora pada tanggal 3 Desember 1970. Penulis menyelesaikan pendidikan S2 Bidang IImu dan Teknologi Pangan Universitas Gadjah Mada Yogyakarta. Sekarang penulis bekerja sebagai staf peneliti di Balai Besar Penelitian dan Pengembangan Pascapanen Pertanian, Departemen Pertanian.

Widaningrum, dilahirkan di Sukabumi pada tanggal 7 April 1979. Penulis menyelesaikan pendidikan S1 Bidang Teknologi Pangan, FATETA, IPB. Sekarang penulis bekerja sebagai staf peneliti di Balai Besar Penelitian dan Pengembangan Pasca Panen Pertanian, Departemen Pertanian. 